Драгана Грујић

Универзитет у Београду

Филолошки факултет
УДК 316.774:37.018.43-057.875

ДОИ https://doi.org/10.18485/

melissa.2016.15.2.ch9

\title{
СТАВОВИ СТУДЕНАТА ФИЛОЛОШКОГ ФАКУЛТЕТА У БЕОГРАДУ ПРЕМА ДИГИТАЛНОЈ ПИСМЕНОСТИ
}

\section{Сажетак}

Широк дијапазон предмета на Катедри за библиотекарство и информатику Филолошког факултета Универзитета у Београду, у које је уткано овладавање вештином дигиталне писмености, студентима омогућава да имају активну улогу у учењу и истраживачким процесима. Циљ је да студент буде оспособљен да дигиталну технологију користи даље у свом образовању, усавршавању, послу...

Колико утоме имамо успеха? Колико су студенти оспособљени да претражују, селектују и вреднују добијене информације? Какви су ставови студената према дигиталној писмености? Како бисмо добили одговоре на ова питања спровели смо истраживање међу студентима. Рад настоји да на основу добијених одговора студената утврди колико студенти знају о дигиталној писмености и у којој мери поседују дигиталне компетенције.

Кључне речи: дигитална писменост, дигитална технологија, информационокомуникационе технологије, студенти, Катедра за библиотекарство и информатику, Филолошки факултет Универзитета у Београду

\section{Врсте писмености с посебним освртом на дигиталну писменост}

Писменост је, посебно са развојем информационо комуникационе технологије, превазишла елементарни вид језичке писмености правилночитање и писање и функционалну језичку писменост-спососбност да се правилно писање и говор примењују у свакодневном животу. Огроман потенцијал нових технологија са једне стране подстиче слободу изражавања, али истовремено доноси велики број дезинформација што је довело до појаве нових видова писмености: библиотечке, информа- 
ционе, медијске, информатичке, дигиталне... као и декларације, смернице, препоруке... које истичу њихов значај. ${ }^{1}$ Све су у једном сагласне - у савременом друштву неопходно је знање саткано од информација у различитим облицима и скуп вештина и компетенција.

Иако се на почетку 21. века много писало о опстанку библиотека, пораст информација је само скренуо пажњу на значај ових установа. Библиотечка писменост је зачетак развоја других врста писмености. Сматра се претечом информационе, а подразумева коришћење библиотечких услуга и извора. Заслуге за увођење појма информациона писменост приписују се Полу Зурковском који је 1974. дао дефиницију „информацијска писменост представља сврсисходно коришћење информација у контексту решавања проблема“. ${ }^{2}$ Уз информациону писменост често се среће термин информатичка/рачунарска писменост, међутим, реч је о сродном али ипак различитом концепту. Информатичка писменост је ужи појам од информационе, јер је ограничена само на употребу и коришћења рачунарских система и програма. Информациона писменост, због количине информација у електронском облику, подразумева и рачунарску писменост, али не и обрнуто. Близак њима је и појам медијска писменост који се односи се на способност критичког вредновања информација добијених путем масовних медија.

Са развојем дигиталне технологије и њеним интегрисањем у све аспекте живота превазилазе се оквири наведених врста писмености.

1 Прашка декларација „Према друштву информационо писмених“, 2003. године (Prague Declaration „Towards an Information Literate Society") http://www.unesco.org/ fileadmin/MULTIMEDIA/HQ/Cl/Cl/pdf/PragueDeclaration.pdf

Александријска декларација „Светионици информационог друштва“ 2005. године (Alexandria Declaration „Beacons of the Information Society”) http://www.ifla.org/ publications/alexandria-manifesto-on-libraries-the-information-society-in-action;

Фешка декларација о медијској и информационој писмености, 2011. године (Fez Declarationon Media \& Information Literacy) http://www.unesco.org/fileadmin/ MULTIMEDIA/HQ/Cl/Cl/pdf/news/Fez\%20Declaration.pdf

Ифла препоруке, Хаг, 2011. године - http://www.ifla.org/publications/ifla-media-andinformation-literacy-recommendations

Московска декларација о медијској и информационој писмености, 2012. године (Moscow Declaration on Media and Information Literacy) http://www.ifla.org/ publications/moscow-declaration-on-media-and-information-literacy

Декларација о обавезном медијском и информационом образовању (UNESCO) http:// www.unesco.org/new/fileadmin/MULTIMEDIA/HO/Cl/Cl/pdf/PragueDeclaration.pdf

2 David Badwen, „Information and digital literacies: a review of concepts," Journal of Documentation 57, no. 2 (2001): 218-259, doi:https://doi.org/10.1108/EUM0000000007083. 
Дигитална писменост је термин који обухвата низ вештина, попут познавања ИТ технологије, проналажења информација, критичке евалуације, креативности и етичког понашања у дигиталном окружењу. Пол Гилстер дефинше дигиталну писменост као способност да се разумеју и користе информације добијене у различитим форматима из различитих извора путем рачунара. ${ }^{3}$ Дигитално писмена особа треба да поседује способност проналажења, оцене и не само коришћења већ и стварања новог садржаја путем технологије и интернета. У литератури се често може приметити двојак однос према дигиталној медијској технологији - технооптимистички и технопесимистички. ${ }^{4}$ Према аутору текста Дигитална средства и сврха образовања, Саши Радојчићу, најбоље је компромисно решење: „Образовни систем обухвата нове медије 'образовањем за медије' и њиховом применом као образовне технологије ... дигиталне медијске технологије нису сврха, већ средство у образовном процесу... оне су средство које мења карактеристике самог тог процеса и хуманистички схваћена сврха образовног процеса није укинута упркос тим променама.“5

Како је реч о комплексном појму, ова врста писмености је дефинисана и помоћу компетенција. Дигиталне компетенције се данас посматрају као предуслов, али и право свих грађана да квалитетно функционишу у савременом друштву. ${ }^{6}$ На значај ове области указују и многобројне смернице и оквири за развој и разумевање дигиталних компетенција. ${ }^{7}$ Међу њима најпознатији је

3 Paul Gilster, Digital Literacy (New York: John Wiley \& Sons, 2001), 1.

4 Vladimir Kopicl, ur. i prev, Tehnoskepticizam: mala čitanka tehno delirijuma (Novi Sad: Orpheus, 2007), 31; Saša Radojčić, „Digitalna sredstva i svrha obrazovanja“, Kultura: časopis za teoriju i sociologiju kulture i kulturnu politiku br. 135 (2012): 15

5 Saša Radojčić, „Digitalna sredstva i svrha obrazovanja“, Kultura: časopis za teoriju i sociologiju kulture i kulturnu politiku br. 135 (2012): 13

6 Anusca Ferrari, "Digital Competence in Practice: An Analysis of Frameworks" (2012): 4-7, http://ftp.jrc.es/EURdoc/JRC68116.pdf. (преузето 4.9.2016)

7 Унескове смернице о ИКТ за наставнике (UNESCO ICT Competency Framework for Teachers - http://www.unesco.org/new/en/communication-and-information/resources/ publications-and-communication-materials/publications/full-list/), Оквир за развој и разумевање дигиталних компетенција у Европи (DIGCOMP: A Framework for Developing and Understanding Digital Competence in Europe - http://ipts.jrc.ec.europa.eu/publications/ pub.cfm?id=6359) Европски оквир дигиталних компетенција за образовне организације (A European Framework for Digitally-Competent Educational Organisations - https:// ec.europa.eu/jrc/en/digcomporg), Пројекат Европске комисије Дигиталне компетенције 
Дигкомп - Оквир за развој и разумевање дигиталне компетенције у Европи (DIGCOMP - A Framework For Developing And Understanding Digital Competence In Europe). ${ }^{8}$ Донела га је Европска комисија 2013. године којом је дигитална компетенција окарактерисана као једна од осам кључних компетенција које су предуслов за доживотно учење. Према овоме дигитална компетенција је дефинисана као критичка и креативна употреба информационо комуникационе технологије у остваривању циљева у најширем смислу (учење, усавршавање, слободно време, учешће у друштву...). Према Унеску она је предуслов да се стекну и развију друге компетенције и вештине за 21. век. ${ }^{9}$

У Србији је Министарство просвете, науке и технолошког развоја 2015. године, у оквиру Отвореног метода координације у области образовања и обуке Европске уније, формирало Радну групу за дигитално и онлајн учење и развој међупредметних компетенција са фокусом на информационо-комуникационе технологије са циљем да се изради Национални оквир дигиталних компетенција. Наредне године, 2016, креиран је нацрт оквира дигиталних компетенција Наставник за дигитално доба „са циљем да подржи наставнике из система образовања у Србији у процесу интеграције дигиталних садржаја у свакодневну праксу“. ${ }^{10}$ Оквир дигиталних компетенција односи се и на наставнике универзитета „како би успешно функционисао у систему дигиталног образовања“. ${ }^{11}$ Као одговор на потребу стицања и развијања дигиталне писмености неопходно је интегрисање дигиталних технологија у студијске програме. ${ }^{12}$

за наставнике (Digital Competences for Teachers - http://www.digital-competences-forteachers.eu/?page_id=69), Оквир Партнерства за учење у 21. веку (P21's Framework for 21st Century Learning - http://www.p21.org/our-work/p21-framework)

8 Anusca Ferrari, "DIGCOMP - A Framework For Developing And Understanding Digital Competence In Europe“ (2013), http://ftp.jrc.es/EURdoc/JRC83167.pdf (преузето 4.9.2016)

9 "Digital Literacy in Education" http://unesdoc.unesco.org/images/0021/002144/214485e. pdf (преузето 28.8.2016)

10 Оквир дигиталних компетенција: Наставник за дигитално доба - нацрт, http:// www.mpn.gov.rs/wp-content/uploads/2015/08/Okvir-digitalnih-kompetencija.pdf (преузето 28.8.2016)

11 Danijela Šćepanović et al., „Digitalne kompetencije univerzitetskih nastavnika“, XXIII skup Trendovi razvoja: Položaj visokog obrazovanja i nauke u Srbiji, Zlatibor, 22. - 24. 02. 2017, http:// www.trend.uns.ac.rs/stskup/trend_2017/radovi/T1.2/T1.2-2.pdf (преузето 20.8.2017)

12 Patricia Wastiau et al., "The Use of ICT in Education: a survey of schools in Europe", European Journal of Education Vol. 48, 1 (2013): 11-27, doi:10.1111/ejed.12020 


\section{Ставови студената Филолошког факултета у Београду према дигиталној писмености}

Широк дијапазон предмета на Катедри за библиотекарство и информатику Филолошког факултета Универзитета у Београду, у које је уткано овладавање вештином дигиталне писмености, студентима омогућава да имају активну улогу у учењу $и$ истраживачким процесима. Циљ је да студент буде оспособљен да дигиталну технологију користи даље у свом образовању, усавршавању, послу...

Колико у томе имамо успеха? Колико су студенти оспособљени да претражују, селектују и вреднују добијене информације? Какви су ставови студената према дигиталној писмености? Колико су активни у дигиталном окружењу? Како бисмо добили одговоре на ова питања спровели смо истраживање међу студентима.

- Методологија истраживања

Анкета је дистрибуирана током школске 2015/2016. године на часовима и путем мејла међу студентима треће и четврте године (од 53 студената одговорило је 48 студената), као и међу мастер студентима (од 112 студената одговорило је 87 студената). Истраживањем је обухваћено укупно 135 студената основних и мастер студија.

За потребе истраживања наменски је сачињена анкета оддвадесет тврдњи. Од мерних инструмената коришћена је петостепена Ликертова скала. ${ }^{13}$ Добијени подаци изражени су процентуално. Обрада и анализа података, уз примену дескриптвне методе, подразумева преглед унетих података и међусобно упоређивање добијених одговора.

\section{- Резултати и анализа}

Тврдње се могу поделити у три групе. Првих десет питања односи се на познавање проналажења и коришћења информација доступних на Интернету. Други део обухвата тврдње везане за безбедност, а последње три тврдње откривају активности студената у дигиталном окружењу.

13 Сваку понуђену тврдњу студенти су оцењивали оценама од 1 до 5 (1 - упоште се не слажем, 2 - углавном се не слажем, 3 - не знам, неодлучан сам, 4 - углавном се слажем, 5 - потпуно се слажем) 


\begin{tabular}{|l|l|l|l|l|l|l|}
\hline & Тврдња & \multicolumn{3}{|l|}{ Одговор \% } \\
(Ликертова скала)
\end{tabular}




\begin{tabular}{|c|l|c|c|c|c|c|}
\hline 17. & $\begin{array}{l}\text { Често остављам коментаре на блоговима, } \\
\text { форумима, веб страницама... }\end{array}$ & 10 & 17 & 11 & 34 & 28 \\
\hline 18. & $\begin{array}{l}\text { Креирам и ажурирам информације које сам } \\
\text { нашао на мрежи (нпр. Википедија). }\end{array}$ & 18 & 23 & 14 & 25 & 20 \\
\hline 19. & $\begin{array}{l}\text { Умем да креирам различите мултимедијалне } \\
\text { садржаје. }\end{array}$ & 2 & 8 & 10 & 33 & 47 \\
\hline 20. & $\begin{array}{l}\text { Предмети попут информационе и медијске } \\
\text { писмености помогли су ми да развијем } \\
\text { вештине дигиталне писмености. }\end{array}$ & 4 & 7 & 11 & 22 & 56 \\
\hline
\end{tabular}

На основу добијених одговора може се закључити да студенти у великој већини сматрају да знају шта је дигитална писменост (62\%), како да претражују, селектују и чувају информације и да, очекивано, одговоре најпре траже путем интернета (чак $81 \%$ испитаника). Свесни су значаја дигиталне писмености за образовање иза друштвени живот. Ипак, девета и десета тврдња указују да је неопходно да унапреде вештине претраге, посебно приликом одабира релевантних извора. Иако се од студената током студија у бројним семинарским радовима очекује да користе и наводе како штампане тако и електронске публикације, за учење само $26 \%$ испитаника користи различите изворе. Посебно је потребно порадити на обуци студената како да се заштите у дигиталном свету, јер један део не зна шта се дешава са подељеним информацијама. Студенти се већ од прве године упознају са историјатом, развојем и значајем ауторског права. На четвртој и петој години очекује се не само да знају теорију, већ и да примене стечено знање - да поштују ауторско право и да провере услове коришћења пре преузимања неког ауторског дела без обзира на ком се медију налази. Истраживање је показало да постоје студенти који можда и познају ауторско право, али не и како се штити у дигиталном окружењу. Зато је студентима неопходно више истраживачких задатака и праксе како би применили стечено знање. Око трећине испитаника познаје значење термина „дигитални отисак“ и „дигитални идентитет“. Ово је проверено и тврдњом под редним бројем 16 - Дигитални идентитет" је исто ито и „интернет идентитет. Приближно исти проценат се, исправно, није сложио са овиме. Један 
део студената је активан на мрежи, али више остављају коментаре, него што креирају и ажурирају дииталне информације. На Катедри за библиотекарство и информатику постоје изборни предмети - на основним студијама: Информациона писменост и Медијска писменост; на мастер студијама: Информациона и медијска писменост у школској библиотеци и Информациона и медијска писменост науци. Више од половине испитаника (56\%) сматра ову врсту предмета корисним за унапређење дигиталних вештина. Ово је путоказ да овакве премете треба развијати.

\section{Закључак}

Предмет проучавања овог рада били су ставови студената о дигиталној писмености. Пошли смо од очекивања да испитаници имају одређена знања у овој области, управо зато су узорак чинили студенти виших година. Сигурно би слика била другачија да су били укључени и студенти прве и друге године студија. Препрека у извођењу ширих закључака је питање колико студената је са Катедре за библиотекарство и информатику, јер је Катедра интердисцпилинарна па поједине предмете, посебно на мастер студијама, бирају студенти других студијских група. Требало би испитати и упоредити њихова знања, полазећи од претпоставке да студенти на Катедри за библиотекарство и информатику имају више предзнања због предмета који се изучавају.

Резултати су потврдили да су студенти у великој мери активни на мрежи, да знају да претражују информације, али и да су недовољно свесни ризика које информације прикупљене и подељене на овај начин носе. С обзиром на улогу коју факултети имају у трансферу знања и служењу друштву уопште, на њима је и одговорност да допринесу развијању наведених врста писмености. У томе значајну улогу имају и наставници и библиотекари. ${ }^{14}$ Зато је задатак настав-

14 Gordana Djokovic, Dragana Grujic, "Information Literacy and Libraries in University Education", EDULEARN 16: 8th international conference on education and new learning technologies (Barcelona: International Association of Technology, Education and Development (IATED), 2016), 8682-8687. 
ника и сарадника да унапреде студијске програме, да користе дигиталне технологије као важно средство у образовном процесу, да створе услове у којима ће студенти активно учествовати, а самим тим стицаће и развијаће дигиталне компетенције у складу са наведеним препорукама Министарства.

\section{Извори и литература}

Александријска декларација „Светионици информационог друштва“ 2005. године (Alexandria Declaration „Beacons of the Information Society”), http://www.ifla. org/publications/alexandria-manifesto-on-libraries-the-information-society-inaction

Badwen, David. "Information and digital literacies: a review of concepts." Journal of Documentation 57 no. 2 (2001): 218-259. doi:https://doi.org/10.1108/ EUM0000000007083.

Декларација о обавезном медијском и информационом образовању (UNESCO), http://www.unesco.org/new/fileadmin/MULTIMEDIA/HQ/Cl/Cl/pdf/ PragueDeclaration.pdf

"Digital Literacy in Education" http://unesdoc.unesco.org/images/0021/002144/ 214485e.pdf (преузето 28.8.2016)

Djokovic, Gordana, Dragana Grujic. "Information Literacy and Libraries in University Education", EDULEARN 16: 8th international conference on education and new learning technologies (Barcelona: International Association of Technology, Education and Development (IATED), 2016), 8682-8687.

Ифла препоруке, Хаг, 2011. године, http://www.ifla.org/publications/ifla-media-andinformation-literacy-recommendations

Kopicl, Vladimir, ur. i prev. Tehnoskepticizam: mala čitanka tehno delirijuma. Novi Sad : Orpheus, 2007.

Московска декларација о медијској и информационој писмености, 2012. године (Moscow Declaration on Media and Information Literacy), http://www.ifla.org/ publications/moscow-declaration-on-media-and-information-literacy

Оквир дигиталних компетенција: Наставник за дигитално доба-нацрт, http:// www.mpn.gov.rs/wp-content/uploads/2015/08/Okvir-digitalnih-kompetencija. pdf (преузето 28.8.2016)

Прашка декларација „Према друштву информационо писмених“, 2003. године (Prague Declaration „Towards an Information Literate Society”)

Radojčić, Saša. „Digitalna sredstva i svrha obrazovanja“. Kultura: časopis za teoriju i sociologiju kulture i kulturnu politiku br. 135 (2012): 13-19.

Ferrari, Anusca. "Digital Competence in Practice: An Analysis of Frameworks" (2012), http://ftp.jrc.es/EURdoc/JRC68116.pdf. (преузето 4.9.2016) 
Ferrari, Anusca. "DIGCOMP - A Framework For Developing And Understanding Digital Competence In Europe“ (2013), http://ftp.jrc.es/EURdoc/JRC83167.pdf (преузето 4.9.2016)

Gilster, Paul. Digital Literacy . New York : John Wiley \& Sons, 2001.

Фешка декларација о медијској и информационој писмености, 2011. године (Fez Declarationon Media \& Information Literacy) http://www.unesco.org/fileadmin/ MULTIMEDIA/HQ/Cl/Cl/pdf/news/Fez\%20Declaration.pdf

Šćepanović, Danijela, Uglješa Marjanović, Isidora Korać, Darko Stefanović. „Digitalne kompetencije univerzitetskih nastavnika". XXIII skup Trendovi razvoja: Položaj visokog obrazovanja i nauke u Srbiji, Zlatibor, 22. - 24. 02. 2017, http://www. trend.uns.ac.rs/stskup/trend_2017/radovi/T1.2/T1.2-2.pdf

Wastiau, Patricia, Roger Blamire, Caroline Kearney, Valerie Quittre, Eva Van de Gaer, Christian Monseur. "The Use of ICT in Education: a survey of schools in Europe". European Journal of Education Vol. 48, 1 (2013): 11-27. doi:10.1111/ejed.12020

\section{Dragana Grujić \\ University of Belgrade \\ Faculty of Philology}

\section{ATTITUDES OF STUDENTS OF THE FACULTY OF PHILOLOGY IN BELGRADE TOWARDS DIGITAL LITERACY}

\section{Summary}

The broadband of subjects at the Department of Library and Information Science, Faculty of Philology University of Belgrade, develop students' digital literacy competence. This enable students to play an active role in learning and research processes. The aim is to enable our students to use digital literacy benefits further in their education, training, work ...

How successful are we? What is the rate of our students' ability to search, select and evaluate relevant information? What are the attitudes of students towards digital literacy? In order to find the answers to all these above, we have questioned our students. The aim of the research is to check our students' level of digital literacy and digital competence.

Key words: digital literacy, information-communication technology, students, Department of Library and Information Sciences, Faculty of Philology Belgrade University 